\title{
ON PRONOMINALIZATION CONSTRAINTS IN CATALAN: THE ROLE OF INFORMATION STRUCTURE
}

\author{
MONTSERRAT FORCADELL
}

\begin{abstract}
Although it is true that some pronominalization phenomena are restricted by grammatical or semantic factors, others are better accounted for on informational grounds. Pronominalization is triggered not only by material which is omitted but also by material which is dislocated; therefore, the informational status of pronominalizable strings should also be taken into account, since thematic material must always occupy a dislocated position in Catalan, and dislocation may require clitic binding. Furthermore, as in Catalan sentence structure is intimately associated with prosody (with primary accent marking sentence boundary), considering the relationship between structure and prosody is vital for a unified account on pronominalization, since by doing so, some grammatical phenomena ruled out by some constraints posited in the literature will be accounted for.
\end{abstract}

\section{INTRODUCTION}

Some cases of pronominalization in Catalan have been accounted for on independent grammatical rules. For instance, subjects do not pronominalize because there is a gap in the clitic paradigm for subjects. Likewise, complements of a subject head noun do not pronominalize either. Compare the ungrammatical sentence "La història sociolingüistica del català n'ha condicionat l'ús [The sociolinguistic history of Catalan has conditioned its use $]^{1}$ with the grammatical one: Les reformes a les central nuclears d'Ascó podran allargar-ne deu anys la vida [The remodeling of the nuclear plants in Ascó will add ten years of life to them] (Todolí 1365). However, there does not seem to be a unified framework that explains the data and covers closely related phenomena, since productive cases of Catalan pronominalization are discarded by such grammatical rules. Although it is true that a specific grammatical context might prevent pronominalization, it is not always the case that such a constraint applies across the board, since instances of grammatical sentences presenting similar contexts would be ruled out.

Likewise, it may also be true that specific semantic features of certain items involved in pronominalization may play a relevant role in its viability. Compare, for instance, the ungrammatical sentence "Si vols tenir les dents més netes, hauràs de comprar-te'n un raspall [If you want to have cleaner teeth, you will have to 
buy a (tooth)brush] (Todolí 1386) with its grammatical counterpart, without clitic binding, Si vols tenir les dents més netes, hauràs de comprar-te un raspall. In that case, the head raspall [brush] and its complement de dents [of teeth] (literally) function as a compound; therefore, the complement will not pronominalize, as they form a referential unit.

However, pronominalization cannot be explained on semantic or grammatical grounds only. It seems that a specific informative and therefore syntactic (i.e., dislocated) status of the potentially pronominalizable strings is needed for those features to play a role. To exemplify this, I will deal with data discussed by Todolí mainly, since her description of Catalan pronouns and pronominalization is not only thorough but comprehensive as well. The objective of this piece of work is, therefore, to show that, apart from certain specific semantic and grammatical constraints that may operate in preventing pronominalization in Catalan, the informational status of the potentially pronominalizable strings will play a major role in clitic binding. As I will sketch in the next section, in Catalan, the identification of the sentence's primary accent will be crucial in describing pronominalization, since primary accent marks the right boundary of the clause, which contains rhematic information. Thematic material will necessarily occupy a position of dislocation, which implies that pronominalizable material will always appear in a dislocated slot. I will show that taking information structure into account will provide for a more comprehensible and unified explanation of pronominalization in those cases when the pronominalized material has not been omitted but marked as thematic, appearing in a position of dislocation.

It must be mentioned that the examples discussed in this paper mostly concern clitic en, except for a couple that involve clitic $h i$. This is due to the fact that those restrictions posited by Todolí in her chapter deal mainly with clitics en and hi as well. Todolí mentions that these clitics are invariable and, therefore, since they do not establish any concord with their antecedent, they have a looser bond with it (Todolí 1364). Furthermore, clitic en pronominalizes for a wider number of constituents of a varied nature (determinerless objects and unaccusative subjects, some copular predicates, and PP complements headed by the preposition $d e$ ) than the other clitics. This might also favor the existence of a higher number of constraints involving the same clitic. 


\section{THE REALIZATION OF THE INFORMATIONAL LEVEL IN CATALAN}

In Catalan, the position of the primary accent is closely related with information structure since it marks the right boundary of the clause, which contains rhematic material. ${ }^{2}$ Thematic material will occupy left- or right-dislocated slots. Thus, prosody is directly associated with syntactic structure, since Catalan draws basically on syntax to express the partition between theme and rheme (Vallduví, The Informational Component; "Detachment;" "L'oració"). Other languages such as English may reflect that partition mainly through prosody (Selkirk; Rochemont). ${ }^{3}$

Hence, since in Catalan, following Vallduví, the item that receives primary accent is always the last accentable element of the rheme, the element carrying the accent marks off the right-boundary of the clause. Thus, the deaccented linguistic material that follows is deemed, in pragmatic terms, as part of the theme, and, in syntactic terms, it is considered to fall outside the core clause, as illustrated by the brackets in B's reply in example (1) below, for instance. ${ }^{4}$ The object la Maria appears outside the rheme ( $\mathrm{Rh})$, in a deaccented phrase. It is right-dislocated and, therefore, it must accordingly comply with the syntactic requirement that is posed by its extraction from the clause: the binding of a clitic in canonical position to fulfill the subcategorization needs of the verb. ${ }^{5}$ Compare sentence (1B), which presents a right-dislocation, with the ungrammatical cliticless utterance in (2). This non-standard example reflects a prosodic strategy available in English (in situ accent-shift), which allows the shifting of primary accent onto any element in the clause that needs to be marked for focus: [I don't KNOW Maria $]_{S}$. Thus, in English, unlike in Catalan, the deaccented thematic material after primary accent need not be moved to a dislocated position; it may remain clause-internally (i.e., it may be shifted in situ).

(1) (A: Per què no la vas convidar, la Maria?)

B: $\left[\text { No la }_{\mathrm{i}} \text { CONEC, }\right]_{\mathrm{Rh}}$ la $\mathrm{Maria}_{\mathrm{i}}$ not CL know.1SG the Maria.

[I don't know Maria.]

(2) *No CONEC la Maria.

Dislocation can also go to the left, as shown in example (3). In Vallduví's model, the informational functions associated with left- and right-dislocation are not the same. Left-dislocated constituents function as links, whereas right-dislocated constituents function as tails, although both are part of the ground. However, in this paper, no distinction will be made as to the specific pragmatic function 
of thematic material, since this would be beyond the scope of this work. What is relevant is that both positions are thematic. Thus, the term theme will be used to refer to Prince's "inferable" and ("situationally" and "textually") "evoked" entities, and the term rheme will refer to Prince's "brand new" and "unused" entities; i.e. non-salient or non-activated entities, without further distinction.

(3) La Maria ${ }_{i}$, [no la $\mathrm{i}_{\mathrm{i}}$ CONEC. $]_{\mathrm{Rh}}$

The dislocated constituents may be of a varied syntactic nature and there may be multiple dislocation. ${ }^{6}$ In that case, the constituents can be ordered freely since they are not restricted by the linear constraints that operate inside the sentence, as shown in $(4 \mathrm{a}-\mathrm{b})$, which present left-dislocation of two phrases, les copes [the glasses] and al celler [in the cellar]. The same would apply to right-dislocation. See Vallduví, "Detachment" $576 \mathrm{n} .2$ for an inventory of clitics and their coreferential dislocated material.

(4) (A: Let's keep the glasses in the cellar.)

a. B: Les copes $s_{i}$, al celler ${ }_{i}$, no les $\mathrm{hi}_{\mathrm{j}}$ DESAREM. the glasses in.the cellar, not CL CL will.keep.1PL

b. B: Al celler ${ }_{j}$, les copes ${ }_{i}$, no les ${ }_{i} h_{j}$ DESAREM. in.the cellar the glasses not CL CL will.keep.1PL

Since Catalan syntax reflects the informational status of sentence constituents by placing thematic material in peripheral (dislocated positions) to mark pragmatic information, standard Catalan may not resort to prosodic strategies such as accent-shift in situ, which is very productive in English, to mark the focus. Furthermore, in Catalan sentences, only one accent is perceived with maximal prominence (Prieto), marking sentence right-boundary. Thus, although there are two detached positions (left- and right-dislocation) for the encoding of thematic material, right-dislocation in Catalan is easily identified since it is directly associated with primary accent position: the deaccented phrase following primary accent will be right-dislocated and, therefore, may trigger clitic binding in the clause. Left-dislocated material will also trigger clitic binding but will precede the primary accent, the one with maximal prominence.

Hence, since Catalan sentence structure is directly associated with prosody for the mapping of the theme-rheme partition, we should take primary accent position into account when explaining pronominalization of either omitted or dislocated material, so that the pragmatic and consequent structural nature of pronominalized phrases is not overlooked. 


\section{GRAMMATICAL CONSTRAINTS?}

\subsection{Prepositional phrases}

Pronominalization is affected by the presence of prepositions which might prevent clitic binding. According to Todolí, the phrase that binds the clitic must postmodify a head which must be subcategorized by the verb and, therefore, must be an NP (1386). If it is in a PP, the preposition acts as "some sort of a barrier" between the pronoun and the substituted element and pronominalization is not possible ("double PP boundary" restriction). Now, although it is true that postmodifiers of prepositional objects may not pronominalize, as shown by the ungrammatical sentences in $(5 a-b)$, the sentence in (6) is grammatical even though the dislocated phrase is a postmodifier of a head noun in a PP, flouting the "double PP boundary" constraint. ${ }^{7}$

(5) a. N'ha participat en l'ELABORACIÓ, del document.

[He has participated in the writing of the document.]

b.*Hi creu en l'APLICACIÓ, del protocol.

[He believes in implementing the protocol.]

(6) N'hem fet una crítica de la IMATGE, del noi; no pas del seu comportament.

[We have made an assessment of the public image of the guy; not of his behavior.]

Notice that although the deaccented sequence in example (6) (del noi [of the guy]) is a postmodifier of a noun (imatge [image]) that could be analyzed as a prepositional object taking critica as the support object of the light verb fer [make] (in the construction fer una critica de [make an assessment of] = criticar [criticize]), the substitution of the light verb fer by a verb such as pensar [think] (see example (7a)), which selects a preposition (en), bars clitic binding. However, the substitution of the verb fer [make] with another verb that does not select a preposition, like considerar [consider] in (7b), would still result in a grammatical sentence. These "pseudo-prepositional objects" are also found with sentences with the verb estar [be] plus a predicative with a postmodifier, as illustrated in (8). Notice that in this example the pronominal postmodifier (d'aquesta droga [of this drug]) is not the second but even the third PP. This sentence, however, is grammatical.

(7) a. "N'hem pensat en la crítica de la IMATGE, del noi.

[We have thought in the assessment of the public image of the guy.]

b. N'hem considerat la crítica de la IMATGE, del noi.

[We have considered the assessment of the public image of the guy.]

(8) N'estic al corrent dels EFECTES, d'aquesta droga, però no dels components.

[I am aware of the effects of this drug, not of the components.] 
Likewise, the examples in (9) also flout the "double PP boundary" restriction. These sentences are grammatical; it is the length of the object that makes them cumbersome. ${ }^{8}$ In fact, this "double PP" restriction is also flouted by dislocated postmodifiers of adjective heads, as in (10). In this case, the pronominalized PP amb $m i$ [with me] postmodifies a head (emprenyada [mad]) that is also introduced by a preposition, and, therefore, the substituted complement is also the second PP.

(9) a. El document en proposa l'avaluació del passos INTER MITJOS, del protocol. [The document proposes the assessment of intermediate steps in the protocol.]

b. Aquesta fundació en promou la investigació de les causes SOCIALS, de la malaltia. [This foundation promotes the research of the social causes of the disease.]

(10) La Maria hi continua igual D'EMPRENYADA, amb mi.

[Maria is still mad at me.]

Hence, the double PP restriction seems to apply to postmodifiers of prepositional objects only, as in $(5 \mathrm{a}-\mathrm{b})$. If the postmodifier of an NP in a PP is thematic, it must occupy a dislocated position and, therefore, a clitic may be bound if required by that specific kind of postmodifier (see n. 6), no matter the number of PPs.

\subsection{Ordinal and relational adjectives}

Pronominalization may also involve noun heads modified by ordinal or relational adjectives. Todolí (1381) argues that complements of nouns may be left outside the operation of pronominalization sometimes, and that this is what offers the possibility for some of these complements to block the substitution of the head of the NP. Consider Todoli's examples reproduced here in (11) and (12). ${ }^{9}$

(11) Només quedaven per vendre dos segons pisos i tres tercers. "Ens $n$ 'hem quedat un (de) segon i dos (de) tercers.

[There were only two second floor and two third floor apartments [left] for sale. We've bought one first floor and two second floor apartments.]

(12) "'Les pistes d'esquí estaven gelades, però encara $n$ 'hem pogut fer dues (de) vermelles i dues (de) verdes.

[The slopes were frozen, but we managed to go down two red pistes and two green ones.]

Todolí mentions that the pronominalization in (11) is not possible, probably because the ordinal (segon [second], tercer [third]) functions as the head of the $\mathrm{NP}$ and, therefore, the clitic and the ordinal would both be related to the same syntactic function. She also refers to the classifying character of the adjective in (12), which implies that these adjectives function as some kind of argument since they are selected by the head, unlike plain qualifiers, which just add an extra 
quality to it. The intimate relationship that the relational adjectives (vermelles [red], verdes [green]) in (12) have with their head (i.e., they denote types of slopes) is what, according to Todolí, prevents the substitution of the head only, but allows for the substitution of both head and complement. I believe that the data calls for a different kind of analysis.

On the one hand, preposition de in Todoli's examples (11) and (12) is not optional (e.g., Ens n'hem quedat un de segon $i$ dos de tercers vs. "Ens n'hem quedat un segon $i$ dos tercers), contrary to what the parentheses in her examples indicate. On the other hand, the absence of the clitic ( $\left.n^{\prime}\right)$ would render both sentences ungrammatical (e.g., "Ens hem quedat un de segon $i$ dos de tercers).

Now, Todoli's grammatical alternatives to (11) and (12), given in (13) and (14), present sequences either with the ordinal head substituting for the entire NP (and, therefore, no clitic need be bound), as in (13), or sentences with left-dislocated ordinals with the corresponding clitic in situ, as in (14).

(13) a. Ens hem quedat un segon i dos tercers.

[We've bought one first floor and two second floor apartments.]

b. Encara hem pogut fer dues vermelles i dues negres.

[The slopes were frozen, but we managed to go down two red pistes and two green ones.]

(14) a. De segon, me n'he quedat un i de tercers, m'he n'he quedat dos.

b. De vermelles i de negres n'hem fet dues. ${ }^{10}$

However, these grammatical alternatives correspond to two different grammatical analyses of the noun head and/or the postmodifier which are not reflected in the way she presents examples (11) and (12), since the preposition (de) is considered optional for both analyses, discarding the possibility of including it (Ens n'hem quedat un de segon i dos de tercers), as suggested above. Naturally, the omission of the preposition allows for the reanalysis of the ordinal and/or relational adjective as substituting for the whole NP, thus preventing the binding of the clitic, as seen in the cliticless alternatives in (13). However, the presence of the preposition calls for a different interpretation of the structure; that is, as presenting a dislocated NP (de pisos) after primary accent (e.g., Ens n'hem quedat un de segon i dos de TERCERS, de pisos). Likewise, the pronominalized heads in (14a) come in pairs as contrastive topics, calling for left-dislocations; however, if we simplify the example to remove the contrast between topics, we may have right-dislocations as well, as in $(15 \mathrm{a}-\mathrm{b})$. Hence, the presence of the preposition de is not optional but totally dependent on the analysis of the adjective either as an NP in situ (without the preposition), as in (13), or as being dislocated (requiring the preposition), as in (14) and (15). 
(15) a. Ens agraden molt els pisos alts i ens n'hem quedat DOS, d'àtics.

[We love top floor apartments and we got two penthouses.]

b. Tot estava gelat, però n'hem pogut fer DUES, de negres.

[It was all frozen but we could go down two black pistes.]

In fact, ordinals and relational adjectives do not behave differently from simple qualifiers such as calents [hot] in another of Todolís (1378) examples, reproduced here in (16). In the sentences in (17), we see that the three types of adjectives may substitute for the head noun, which is pronominalized by clitic en/n'. However, what makes ordinal and relational adjectives different from plain adjective is that the qualifier calents may not function as the head of the NP, as shown by ungrammatical (18a).

(16) - Han portat entrepans freds? - No. N'han portat dos de calents.

[Have they brought any cold sandwiches? No. They've brought two hot ones.]

(17) a. N'han portat DOS, de calents.

[They brought two hot ones.]

b. Me n'he quedat UN, de segon.

[I got a second floor one.]

c. N'hem fet UNA, de vermella.

[We have gone down a red one.]

(18) a. "Han portat dos calents.

b. Ens hem quedat un segon.

c. Hem fet una vermella.

Hence, although the semantic type of adjectives will be relevant to explain specific idiosyncratic grammatical behavior, it seems that adjectives in general will still conform to the rules imposed by the mapping of information onto structure, which, in turn, is directly associated with specific sentence slots. The presence of preposition $d e$, for instance, will depend on a specific structural configuration, which will be motivated by the informative status of the linguistic material involved.

\section{SEMANTIC CONSTRAINTS?}

\subsection{Pronominalization depending on (pragmatic) function of antecedent}

Different postmodifiers in NPs behave differently as to pronominalization, since there are syntactic and semantic factors that will (dis)favor pronominalization of postmodifiers (see n. 6). Among those that may bind a clitic when omitted or deaccented/ dislocated, we find a case that Todolí (1385) ranks as difficult to pronominalize if the antecedent (as she calls it) has a specific meaning and 
reference, as she illustrates with the example in (19a). ${ }^{11}$ According to Todolí, it is preferable to dispense with the clitic, as in (19b).

(19) a. "Vaig anar a Girona i en vaig visitar la catedral.

b. Vaig anar a Girona i vaig visitar la catedral.

[I went to Gerona and I visited the cathedral.]

However, there might be an explanation for the preference (not) to bind a clitic in such cases, which might be based on other grounds. Pronominalization might not depend on a specific semantic feature of the antecedent but on a combination of its pragmatic value and a more general semantic factor. Compare (19b) with (20). If the phrase de Girona [of Gerona] in (20) is presented as setting a restricting frame out of which an element (la catedral [the cathedral]) is singled out in order to predicate something of that element, the clitic is required. That is, if a wholepart relationship is established between de Girona and la catedral (i.e., "out of the things that one can visit in Gerona I visited the cathedral”), pronominalization is favored.

(20) Jo, de Girona, en vaig visitar la catedral.

[I visited the cathedral of Gerona.]

Notice that pronominalization would also be allowed if the coreferential phrase of clitic en (de Girona) was right-dislocated, as in (21), rather than located in a left-dislocated, anaphoric position, as in (20). It seems then that the category restrictor phrase de Girona, being in a dislocated position (left or right) and, therefore, being marked as thematic, is allowed to bind a clitic. Notice that in a sentence such as Jo vaig dibuixar la catedral de Girona [I drew Gerona's cathedral], de Girona would not be a pronominalizable postmodifier (e.g., *En vaig dibuixar la CATEDRAL, de Girona; see n. 6). Therefore, it seems that clitic binding in (20) and (21) is triggered by a combination of two factors related to the antecedent (de Girona), which is in fact a postmodifier: a) its thematicity, which will require its location in a dislocated slot, and b) its category restricting value, which is intimately related with its thematic value as well (i.e., when a category is restricted to predicate something of one of its members, it automatically becomes thematic).

(21) Jo, en vaig visitar la CATEDRAL, de Girona

Furthermore, Bel (1103) gives sentence (22a) to exemplify the capacity of clitic en to substitute for complements of direct object heads. In that case, Todolís restriction would not hold for example (22a), since Lleida is also a specific referent in this sentence. However, even though reversing the position of the antecedent and presenting it cataphorically (right-dislocated), as in (22b), makes pronominalization 
clearly less acceptable, to my mind, both sentences in (22) are rather odd (??/* Si vas a Lleida, tasta'n els pastissos??; ??" Tasta'n els pastissos, si vas a Lleida), as odd as that of (19a). Although the syntactic structures for the antecedents of the pronominalized phrase in sentences $(19 \mathrm{a})$ and $(22 \mathrm{a}-\mathrm{b})$ are not the same, since they present coordinate and subordinate constructions, respectively (which involves different c-command relations), in none of the three cases are the antecedents (i.e., referents) to be analyzed as a category restrictor, as the presence of the preposition $d e$ [of] in sentences (20) and (21) indicates, since they just set a scene (Girona, Lleida) (19a) or a condition linked to that scene (22a-b).

(22) a. Si vas a Lleida, tasta'n els pastissos.

[If you go to Lleida, you should taste the pastries.]

b. ??/*Tasta'n els pastissos, si vas a Lleida.

[If you go to Lleida, you should taste the pastries.]

Hence, clitic binding does not seem to be governed by either inherent semantic features of the antecedent, like the encoding of a specific meaning or reference, as in example (19); rather, clitic binding, or pronominalization, seems to be a grammatical reflection of the (thematic) informative status of the postmodifiers involved, which will occupy, as a result, specific (thematic/ dislocated) positions.

\subsection{Infinitival postmodifiers: can they not pronominalize?}

Pronominalization of infinitival postmodifiers also appears to be troublesome. Todolí (1387-1388) gives the ungrammatical examples in (23) to illustrate that the partitive pronoun en is banned according to a syntactic restriction on pronominalization by which the pronominalized complement cannot be an infinitival subordinate clause. Instead the VP fer-ho [do this/that] has to substitute for the infinitival postmodifier, as shown in $(24 a-b)$.

(23) a. Jo tinc el costum d'anar al llit aviat. -"Doncs, jo no en tinc el costum.

[I'm in the habit of having early nights. - I am not.]

b. "Encara no m'he mort, però n'he estat a punt.

[I haven't died yet, but I've been close.]

(24) a. Jo tinc el costum d'anar al llit aviat. -Doncs, jo no tinc el costum de fer-ho.

b. Encara no m'he mort, però he estat a punt de fer-ho.

However, and although substituting for the VP fer-ho is always a grammatical option, pronominalizing with clitic en is also grammatical in the case of (23a). Likewise, pronominalization is also possible with clitic $h i$ for cases such as that of (23b), as shown in $(25 \mathrm{a}-\mathrm{b})$, respectively. ${ }^{12}$

(25) a. Doncs, jo no en tinc el COSTUM(, d'anar al llit aviat).

b. Encara no m'he mort, però hi he estat a PUNT(, de morir-me). 
Furthermore, barring those clitics from pronominalizing infinitival postmodifiers and having the substitution with the VP fer-ho in situ as the only alternative would imply that the head nouns (costum, punt) of infinitival postmodifiers can never be accented if rhematic, which amounts to saying that infinitival postmodifiers cannot be thematic. Postmodifiers are deaccentable regardless of their capacity to bind a clitic, and infinitival postmodifiers, which are also quite productive in Catalan, are no exception. Some instances correspond to a pattern where the infinitival postmodifier of the head noun could be reanalyzed as a prepositional object of a verbal construct consisting of a "light verb+support object" construction, as in examples $(26 \mathrm{a}-\mathrm{b})$ (tenir necessitat $[$ have (the) need] = necessitar $[$ need]; tenir traça [have (a) knack] $=$ saber $\left[\right.$ know (how to)]). ${ }^{13}$ Other instances of the same type of pronominalization display an infinitival postmodifier performing other syntactic functions, as in the sentences in (27):

(26) a. Jo no en tinc cap NECESSITAT, de treballar.

[I don't need to work at all.]

b. Els de Texas hi tenien molta TRAÇA, a tancar els negres per càrrecs que no s'aguantaven.

[The Texans had the knack of putting blacks in jail for unsustainable charges.]

(27) a. N'és una MANERA, de resoldre-ho.

[This is a way of solving it.]

b. En valora les REPERCUSSIONS, de dir aquestes coses.

[He is concerned with the impact of saying such things.]

c. Ja en conec els EFECTES, d'actuar així.

[I already know the consequences of acting like this.]

Hence, if the information contained in the postmodifier is thematic, it will be deaccented, as shown in (28a), where the postmodifier is clearly thematic and, therefore, dislocated in B's reply. That does not rule out the possibility of substituting the infinitival with the pronominal VP fer-ho, as in (28b), in which case clitic $e n$ will also be required, as shown by the ungrammatical string in (28c). Notice that although example Doncs, jo no tinc el costum de fer-ho, with the VP fer-ho in canonical position (i.e., treated as rhematic) is common in Catalan, its deaccenting is completely grammatical (28b), as is its omission (Jo tinc el costum d'anar al llit aviat. Doncs, jo no en tinc el costum). However, Todolí rules this last possibility out, as reflected by the asterisk in her example in (23a).

(28) (A: Jo tinc el costum d'anar al llit aviat.)

a. B: Doncs jo no en tinc el COSTUM, d'anar al llit aviat.

b. B: Doncs jo no en tinc el COSTUM, de fer-ho.

c. B: "Doncs jo no tinc el COSTUM, de fer-ho.

[I'm in the habit of having early nights. - I am not.] 
Likewise, infinitival postmodifiers of adjective heads may also pronominalize with clitics $e n$ and $h i$, as illustrated in (29) and (30), respectively.

(29) a. N'estic ENCANTADA, de tenir-lo a casa.

[I'm so happy to have him with me.]

b. N'està molt ORGULLÓS, de fer el que fa.

[He's so proud of doing what he is doing.]

(30) a. Hi està AVESSADA, a llevar-se d'hora.

[She is used to getting up early.]

b. No hi estic D'ACORD, a pagar aquest rebut.

[I don't agree to pay this bill.]

It must be noticed that, with adjective heads, the VP fer-ho will not always be a plausible pronominalizer of the postmodifier unless it denotes an action, not simply a state or predication. This is naturally due to the dynamic semantic feature of the verb fer [do]. Consider, for instance, the examples in (31a) and (32b).

(31) a. No n'estic CONTENT, de tenir tot això.

[I am not happy to have all this.]

b. Hi està molt INTERESSAT, en comprar-ho.

[He is very interested in buying it.]

(32) a. No n'estic CONTENT, de fer-ho.

[I'm not happy to do it.]

b. Hi està molt INTERESSAT, en fer-ho.

[He is very interested in doing it.]

Whereas (32b) is the pronominalized counterpart of (31b), the sentence in (32a) is not the corresponding pronominalized version of (31a). That is, the pronominalized VP fer-ho may not substitute for a postmodifier that denotes a state, such as the one in (31a). However, it may substitute for en comprar-lo [in buying it], as in (31b), since en comprar-ho denotes an action. Thus, infinitival clauses functioning as postmodifiers may pronominalize and are quite productive as well, appearing in both NPs and AdjPs performing a variety of functions.

\section{CONCLUSION}

Although the grammatical or semantic nature of some specific material (such as prepositional objects) might restrict their pronominalization potential, the informative (i.e., thematic) status of the strings that are candidate for pronominalization seems to account for their viability more systematically. This should not come as surprise since pronominalization is an operation triggered not 
only by omitted material but also by thematic material still present in the structure, but located in peripheral (dislocated) positions, and, therefore, not allowed to satisfy the subcategorization requirements of the verb. Thus, for a more systematic account of pronominalization, it seems to be vital not to disregard the informative status of linguistic material since thematic material will be dislocated, which might, in turn, require clitic binding. Sentence structure is directly associated with prosody (with primary accent marking clause boundary); therefore, the informational import of the elements in the sentence and their structural realization should be considered for a comprehensive and more systematic account of pronominalization.

MONTSERRAT FORCADELL

Universitat de Barcelona

\section{NOTES}

1 The translations, in square brackets, are mine.

2 See Forcadell ("Subject Informational Status") for a discussion on the presence of thematic material inside the clause.

3 For an approach to information packaging, see Erteshik-Shir, and Zimmermann and Féry, among others. As for Catalan, see also Vallduví and Engdahl; and Villalba ("Sobre;" The Syntax).

4 Capitals flag the item bearing primary accent (i.e., nuclear, pitch, or sentence accent). Commas set off dislocated constituents.

5 In Catalan, not all dislocated material requires clitic binding. Subjects, for instance, do not, since there are no coreferential clitics for them, except for bare and quantified or partitive subjects of unaccusative verbs (e.g., En $n_{i}$ cauen (moltes), de pedres. [(Lots of) stones fall/are falling].

6 Deaccentable (i.e., thematic) constituents are adjuncts, verbal complements, and postmodifiers in NPs and AdjPs. There are also some postmodifiers of certain adverbs that may also be deaccented and coreferential with a clitic when dislocated, but this case is quite marginal. See Forcadell, "Information Packaging."

7 The rephrasing of the dislocated postmodifier by means of a possessive (Hem fet una valoració de la seva imatge) is a common alternative. However, this possibility does not rule out pronominalization.

8 Notice that the postmodifiers intermitjos and socials could be omitted and pronominalization would still be allowed: El document en proposa l'avaluació del PASSOS, del protocol, Aquesta fundació en promou la investigació de les CAUSES, de la malaltia.

9 The question marks and italics are Todolís.

10 Notice the lack of coherence in the use of the comma in these alternatives. In example (14a) (De segon, me n'he quedat un i, de tercers, me n' he quedat dos), the comma is present, marking off the left-dislocated phrase; however, in (14b) (De vermelles $i$ de negres n'bem fet dues), it is absent.

11 The question marks in superscript are Todolís.

12 Compare the grammatical examples in (24) with (i-ii), where the ungrammaticality of the presence of the clitic is probably due to the fact that preposition de can be easily 
substituted with preposition per [for], giving the noun complement an adverbial value of "purpose" (i.e. el valor suficient per poder-m' ho dir [enough guts so that he could tell me]) (i) and la gentilesa sufficient per poder-m'bo dir [kind enough so that he would tell me]). (i) *No en va tenir el VALOR, de dir-m'ho [He didn't dare to tell me] (ii) *No en va tenir la GENTILESA, de dir-m' ho [He was not kind enough to tell me].

13 Nevertheless, it has already been argued in section 3.1 that such distinction does not restrict pronominalization, since only postmodifiers of prepositional objects bar pronominalization. In fact, Todolís example tenir el costum d'anar al llit aviat could be classed in this category of "light verb+support" object (i.e., tenir el costum = acostumar [have the habit $=$ do usually]).

\section{WORKS CITED}

Bel, Aurora. "Les funcions sintàctiques". Gramàtica del Català Contemporani. Eds. J. Solà, M.R. Lloret, J. Mascaró, and M. Pérez Saldanya. Vol. 2. Barcelona: Empúries, 2002. 1075-147.

Erteschik-Shir, Nomi. Information Structure. The Syntax-Discourse Interface. Oxford Surveys in Syntax and Morphology. Oxford and New York: Oxford University Press, 2007.

Forcadell, Montserrat. "Information Packaging, Language Contact and Linguistic Change: Structural Calque in Catalan”. PhD Dissertation. Barcelona: Universitat Pompeu Fabra, 2007.

-. "Subject Informational Status and Word Order: Catalan as an SVO Language". Journal of Pragmatics 53 (2013): 39-63.

Prieto, Pilar. Entonació: models, teoria, mètodes. Barcelona: Ariel. 2002.

Prince, Ellen F. “Toward a Taxonomy of Given/New Information”. Radical Pragmatics. Ed. P. Cole. New York: Academic Press, 1981. 223-55.

Rochemont, Michael. Focus in Generative Grammar. Amsterdam: John Benjamins, 1986.

Selkirk, Elisabeth O. Phonology and Syntax: The Relation between Sound and Structure. Cambridge, MA: MIT Press, 1984.

Todolí, Júlia. "Els pronoms”. Gramàtica del Català Contemporani. Eds. Joan Solà, Maria Rosa Lloret, Joan Mascaró, and Manuel Pérez Saldanya. Barcelona: Empúries, 2002. 1337-433.

Vallduví, Enric. "Detachment in Catalan and Information Packaging”. Journal of Pragmatics 22 (1994): 573-601.

-. The Informational Component. New York: Garland, 1992.

-. "L'oració com a unitat informativa". Gramàtica del Català Contemporani. Eds. Joan Solà, Maria Rosa Lloret, Joan Mascaró, and Manuel Pérez Saldanya. Barcelona: Empúries, 2002. 1221-79.

Vallduví, Enric, and Elisabet Engdahl. "The Linguistic Realization of Information Packaging”. Linguistics 34 (1996): 459-519.

Villalba, Xavier. "Sobre la dislocació a la dreta”. Llengua \& Literatura 7 (1996): 209-34.

-. The Syntax and Semantics of Dislocations in Catalan. Köln: Lambert Academic Publishing, 2009.

Zimmermann, Malte, and Caroline Féry, eds. Information Structure. Theoretical, Typological and Experimental Perspectives. Oxford: Oxford University Press, 2010. 